DOI: $10.17516 / 1997-1370-0470$

УДК 377.4

\title{
Features of Pedagogical Workers Preparation for the Organization and Holding of All-Russian School Olympiads in Municipal Education System
}

\author{
Elena V. Golubnichaya and Marina G. Yanova* \\ Krasnoyarsk State Pedagogical University named after V.P. Astafiev \\ Krasnoyarsk, Russian Federation
}

Received 03.07.2019, received in revised form 12.08.2019, accepted 25.10.2019

\begin{abstract}
The article discusses the features of training teachers to organize and hold the All-Russian School Olympiad in the municipal education system. The authors substantiate the necessity and relevance of teacher training organization for the organization and holding of the School Olympiad in the municipal education system. Specific attention is paid to the normative documents regulating the procedure of the Olympiad. Experience of teacher preparation for the organization and holding of the School Olympiad in municipal education system is considered. The programme of the training seminar "Organization and Holding of the All-Russian Olympiad in the Municipal Education System" is presented.
\end{abstract}

Keywords: All-Russian School Olympiad, organization and holding of the Olympiad, teachers training.

Research area: general pedagogy, history of pedagogy and education.

Citation: Golubnichaya, E.V., Yanova, M.G. (2019). Features of pedagogical workers preparation for the organization and holding of All-Russian school Olympiads in municipal education system. J. Sib. Fed. Univ. Humanit. Soc. Sci., 15(4), 546-553. DOI: 10.17516/1997-1370-0470.

\footnotetext{
(C) Siberian Federal University. All rights reserved

* Corresponding author E-mail address: elena.w.g@yandex.ru; ymg_boss@mail.ru ORCID: 0000-0003-4262-7015 (Yanova)
} 


\section{Introduction}

Currently, addressing the problem of systematic work with gifted children at the state level is determined by the changes associated with the modernization processes in the economy. During these processes the importance of intellectual and creative potential significantly increases, therefore, the problem of selection and support of talented young people in modern education comes to the fore (Chegodaev, 2013: 185). Organization and holding events that activate intellectual and cognitive activity of school students are extremely important, especially among the abundance of forms, methods and types of education that offer a student modern conditions for the modernization of Russian education (Kolomoets, 2017). Academic Olympiads should be distinguished among all forms of work, since they are a peculiar kind of development, formation and evaluation of creative talent (Senicheva, Sokolova, 2015). In the conditions of modern school, School Olympiads, in particular, school subject Olympiads, were and are an effective means of creating motivation for learning, increasing students' cognitive activity, developing their creative abilities, stimulating enhancement and expansion of school students' knowledge of a subject (Kolomoets, 2017). The Olympiad system is aimed at popularizing sciences and identifying talented students. Numerous participants and winners of academic Olympiads became recognized scientists in their fields (for instance, G.Ya. Perel'man) (Sal'nikova, 2016: 50). Accordingly, the All-Russian School Olympiad is an important link in the nationwide system for finding and supporting gifted children and youth. As a source of valuable information about the state of work with gifted school students, demonstrating the level of knowledge, the scope of intellect and thinking of the best students from different regions of the country that form a single educational space, it performs an information and indicator function (Chegodaev, 2013: 186).

\section{Background, methodology and key principles}

The All-Russian School Olympiads is a system of annual subject Olympiads for the students of state, municipal and non-govern- ment education organizations that implement general education programmes (Adol'f, Golubnichaya, 2013: 23). Since 2014, the Olympiad is held in accordance with the Procedure of Holding the All-Russian School Olympiad, approved by the decree of the Ministry of Education and Science of the Russian Federation of November 18, 2013; and since 2015, taking into account the amendments made into the procedure by the decree of the Ministry of Education and Science of the Russian Federation of March 17, 2015 (Ivanov, 2016, 85). Currently, the All-Russian School Olympiad is held annually. Organizational and methodological support, as well as regulatory support for the Olympiad are provided by the Academy of Advanced Training and Professional Retraining of Educators (Sal'nikova, 2016: 50). The Olympiad is held in four stages: school, municipal, regional and final (Table 1) (Prikaz Ministerstva obrazovaniia...).

Based on Table 1, it can be concluded that the school and municipal stages of the All-Russian School Olympiad have the largest number of participants. Thus, according to the Table, local education authorities are responsible for organizing the stages of the Olympiad with the largest number of participants. Ensuring the identification and support of gifted children, both in a separate constituent entity of the Russian Federation and in the state as a whole, depends on the quality of the organization and holding of these stages.

Responsible approach to the organization and holding of the school, municipal and regional stages of the Olympiad in the constituent entities of the Russian Federation will contribute to the formation of the intellectual potential of the country and its intellectual elite.

\section{Statement of the problem}

A system of the Olympiad movement organization has developed in the constituent entities of the Russian Federation. There are following elements of the system: the forms of holding the school and municipal stages of the Olympiad, the operating procedure and the composition of a city/town jury, preparation of the Olympiad tasks by subject and methodological commissions, the forms of school students' 
education and training to participate in the Olympiads (Rozhdestvenskaya, 2013).

Analysis of the characteristics of the organization and holding of the school and municipal stages of the All-Russian School Olympiad demonstrated the need to prepare the following groups of responsible persons:

- a group of organizational support (organizing committee, organizers at the Olympiad venues, the cryptographic commission members, attendants in the classroom and teachers involved into the information support of the Olympiad);

- a group of psychological and pedagogical support (jury, subject and methodological commissions, teachers involved in the preparation of the Olympiad participants, teachers engaged in social and psychological support of the Olympiad participants).

In accordance with the regulatory documents, seven groups of responsible persons involved into organization and holding the school and municipal stages of the All-Russian School Olympiad have been identified by the authors of the presents paper (Table 2).

\section{Methods}

The specific features of professional teacher training to work with gifted children consists in teaching technologies that ensure the development of students' creativity: communication technologies as acceptance of students' creative activity manifestations, as well as technologies of problematic and dialogic training and extracurricular activities. The Olympiad movement should be considered as one of the directions of a municipality's social development aimed at reproducing and forming of its intellectual potential. For successful and effective self-fulfillment of school students, and implementation of their educational needs and creative potential, annual organization of the All-Russian School Olympiad requires constant optimization of managerial and pedagogical activity in the conditions of the municipal education system. The effectiveness of holding the Olympiad for school students undoubtedly depends on the conditions existing in a particular educational institution, but, first of all, on the level of personal and professional readiness of schoolteachers to hold it.

\section{Discussion}

The authors of the present paper believe that teachers preparation for the organization and holding of the All-Russian School Olympiad in the municipal education system should be aimed at improving their theoretical knowledge

Table 1. Stages of the All-Russian School Olympiad

\begin{tabular}{|c|l|l|}
\hline Stage & \multicolumn{1}{|c|}{ Organizer } & \multicolumn{1}{c|}{ The Olympiad Participants } \\
\hline School & \multirow{2}{*}{$\begin{array}{l}\text { Local education au- } \\
\text { thorities }\end{array}$} & $\begin{array}{l}\text { Students of 4-11 grades, who declared their participation on the basis of } \\
\text { their parents' (guardians') consent }\end{array}$ \\
\cline { 3 - 4 } Municipal & $\begin{array}{l}\text { Students of 7-11 grades, participants of the school stage of the current } \\
\text { the participation in the municipal stage of the Olympiad; } \\
\text { winners and prize-winners of the municipal stage of the previous aca- } \\
\text { demic year Olympiad }\end{array}$ \\
\hline \multirow{2}{*}{ Final } & $\begin{array}{l}\text { Public education } \\
\text { authorities of a con- } \\
\text { stituent entity of the } \\
\text { Russian Federation }\end{array}$ & $\begin{array}{l}\text { Students of 9-11 grades, participants of the municipal stage of the current } \\
\text { academic year Olympiad, who scored the number of points necessary for } \\
\text { the participation in the regional stage of the Olympiad; } \\
\text { winners and prize-winners of the regional stage of the previous academic } \\
\text { year Olympiad }\end{array}$ \\
\hline $\begin{array}{l}\text { Ministry of Educa- } \\
\text { tion and Science of } \\
\text { the Russian Feder- } \\
\text { ation }\end{array}$ & $\begin{array}{l}\text { Students of 9-11 grades, participants of the regional stage of the current } \\
\text { academic year Olympiad, who scored the number of points necessary for } \\
\text { the participation in the regional stage of the Olympiad; } \\
\text { winners and prize-winners of the final stage of the previous academic } \\
\text { year Olympiad }\end{array}$ \\
\hline
\end{tabular}


Table 2. Persons responsible for the organization and holding of the school and municipal stages of the All-Russian School Olympiad

\begin{tabular}{|c|c|}
\hline Responsible persons & Functions \\
\hline $\begin{array}{l}\text { Members of the orga- } \\
\text { nizing committee }\end{array}$ & $\begin{array}{l}\text { - determine the organizational and technological model of the school stage of the Olym- } \\
\text { piad; } \\
\text { - ensure the organization and holding of the Olympiad in accordance with the approved } \\
\text { requirements for the conduction of this stage of the Olympiad for each general education } \\
\text { subject, the procedure and relevant sanitary and epidemiological requirements for the ed- } \\
\text { ucation conditions and procedure in an organization at the time of holding the Olympiad; } \\
\text { - carry out coding (de-identification) of the Olympiad works for the participants of the } \\
\text { school stage of the Olympiad; } \\
\text { - are responsible for life and health of the Olympiad participants during the school stage } \\
\text { of the Olympiad }\end{array}$ \\
\hline Jury & $\begin{array}{l}\text { - assess the completed Olympiad tasks in accordance with the approved criteria and meth- } \\
\text { ods for assessing the completed Olympiad tasks; } \\
\text { - carry out the analysis of the Olympiad tasks and their solutions with the Olympiad par- } \\
\text { ticipants; } \\
\text { - carry out on-site demonstration of the Olympiad tasks performed by the participant upon } \\
\text { the request of the Olympiad participant; } \\
\text { - consider appeals of the Olympiad participants in-person; } \\
\text { - determine the winners and prize-winners of the Olympiad based on the rating results of } \\
\text { the completed Olympiad tasks assessment; } \\
\text { - present the Olympiad results to the Olympiad organizer for their approval; } \\
\text { - make and submit an analytical report on the results of the Olympiad tasks implementation } \\
\text { for each general education subject to the organizer of the relevant stage of the Olympiad }\end{array}$ \\
\hline $\begin{array}{l}\text { Members of the } \\
\text { municipal subject and } \\
\text { methodological com- } \\
\text { missions on subjects }\end{array}$ & $\begin{array}{l}\text { - develop requirements for the organization and holding of the school stage of the Olym- } \\
\text { piad taking into account the methodological recommendations prepared by the central } \\
\text { subject and methodological commissions of the Olympiad; } \\
\text { - prepare the Olympiad tasks based on the content of education programmes of the primary } \\
\text { general, compulsory general and advanced secondary general education, and the corre- } \\
\text { sponding area (profile), form sets of tasks for the school stage of the Olympiad taking into } \\
\text { account the methodological recommendations prepared by the central subject and method- } \\
\text { ological commissions of the Olympiad }\end{array}$ \\
\hline $\begin{array}{l}\text { Organizers at the } \\
\text { Olympiad venues: } \\
\text { - the cryptographic com- } \\
\text { mission members, } \bullet \text { at- } \\
\text { tendants in the classroom }\end{array}$ & $\begin{array}{l}\text { - encode and decode works of the Olympiad participants; } \\
\text { - organize the Olympiad holding in accordance with the approved requirements for the } \\
\text { conduction of this stage of the Olympiad for each general education subject, the procedure } \\
\text { and relevant sanitary and epidemiological requirements for the education conditions and } \\
\text { procedure in an organization at the time of holding the Olympiad }\end{array}$ \\
\hline $\begin{array}{l}\text { Teachers involved in } \\
\text { the preparation of the } \\
\text { Olympiad participants }\end{array}$ & $\begin{array}{l}\text { - provide diagnostics of students' abilities in a specific subject; } \\
\text { - involve school students into the Olympiad movement; } \\
\text { - develop and implement individual training programmes for the Olympiad participants in } \\
\text { a particular subject; } \\
\text { - analyze the results of trained participants at each stage of the Olympiad }\end{array}$ \\
\hline $\begin{array}{l}\text { Teachers involved into } \\
\text { the information support } \\
\text { of the Olympiad }\end{array}$ & $\begin{array}{l}\text { - popularize the Olympiad movement among school students; } \\
\text { - involve school students into the Olympiad movement; } \\
\text { - acquaint school students with the Olympiad procedure; } \\
\text { - inform parents about the Olympiad procedure; } \\
\text { - interact with mass media }\end{array}$ \\
\hline $\begin{array}{l}\text { Teachers engaged in } \\
\text { social and psycho- } \\
\text { logical support of the } \\
\text { Olympiad participants }\end{array}$ & $\begin{array}{l}\text { - psychological support for the Olympiad participants; } \\
\text { - activities monitoring the implementation of the law "On Protection of the Rights of the } \\
\text { Child" and other regulatory acts; } \\
\text { - inform parents and teachers on issues related to the identification, development and sup- } \\
\text { port of gifted children }\end{array}$ \\
\hline
\end{tabular}


about the features of children's talent, as well as at development of the professionally relevant qualities necessary to ensure the effectiveness of the process of the participants training and the procedure for holding the Olympiad. In the authors opinion, local education authorities should create conditions for preparing teachers for organizing and holding of the All-Russian Olympiad.

The participants' future depends on the quality of organization of the school and municipal stages of the Olympiad. Therefore, it is extremely important to prepare groups of persons responsible for the organization and holding of the school and municipal stages of the Olympiad in advance. The jury members, for instance, must be ready for the assessment system and appeal procedures in the current academic year, they should be ready to improve the quality of task analyzing and demonstration of participants' works, and to ensure openness of task analyzing materials for the participants after one of the Olympiad stages. And the members of the organizing committee should have legal support for the Olympiad organization. It should be noted that not only school students, but also school management are interested in winning the Olympiads. The fact is that the rating of secondary education institutions, held by the Ministry of Education of the Russian Federation in recent years, that takes into account their participation in the Olympiads, is one of the most important points for monitoring the effectiveness of Russian schools. That is why subject teachers recommend the most promising students, who have great chances not only to participate in other stages, but also to win in the final, to participate in the school stage of the All-Russian Olympiad (Kobzeva, 2016: 489). Preparation for the stages of the All-Russian School Olympiad requires a serious approach to working with students. Most often, such work is as individualized as possible in order to achieve the highest result.

Thus, a teacher's expertise consists not only in identifying gifted and motivated students, but also in making a rational choice of optimal forms of work, in particular, creating an individual educational roadmap for the academic year with possible prolongation (Iva- nov, 2016: 86). Thus, the local government, each education institution and each pedagogical worker separately have an important task of preparing students for the Olympiads and other intellectual and creative competitions, in particular, for the stages of the All-Russian School Olympiad. Like any competition, the subject Olympiad requires training. In the process of preparation, students not only improve their knowledge, but also form their character, the will to win, and the desire for self-improvement. These are immanent features of a successful person. Psychological training plays a very important role in the preparation of school students for the Olympiads of various levels. It is not a secret for anyone that an Olympiad participant experiences stress, and the higher the level of the Olympi$\mathrm{ad}$, the more stressful it is. Not only the participant's result, but his/her psychological health as well, depends on the right mindset. Therefore, it is strongly recommended to involve school psychologists to work with the Olympiad participants (Esipova, Hokhlov, 2017). It is advisable to prepare school students for the Olympiads separately from lessons at school, at the inter-school level, but in close cooperation with school. Thus, teaching the "Olympiad" subjects will be more efficient and, at the same time, schools will be free from the tasks that are not characteristic to them - targeted specific training. Only teachers with sufficient qualifications - leading scientists, schoolteachers, as well as organizers and winners of previous Olympiads can successfully choose tasks for teaching students and give them competent advice (Laletin, 2010: 37).

In 2012, a survey of the participants in the municipal stage of the All-Russian Olympiad of schoolchildren and teachers who prepared them was conducted in Abakan (Adol'f, Golubnichaya, 2013: 24). The survey results analysis confirmed the need to find new forms of teachers training to work with gifted children in the municipal education system. According to the survey of the participants of the municipal stage of the All-Russian School Olympiad in 2012, as well as the teachers who prepared them, pedagogical support for students with signs of giftedness in the education system is 
an important factor. The Olympiad movement in the city of Abakan is gaining popularity among students of municipal budgetary institutions. It should be noted that most participants annually participate in the Olympiad and take part in two or more subject Olympiads. Therefore, it is important to prepare teachers to work with gifted children. The results of the teachers' survey demonstrate that they lack practical and theoretical knowledge necessary for the modification and individualization of the existing educational programmes. In the process of working with gifted children, it should form a specific area, which requires corresponding organizational and pedagogical conditions, and professional readiness of teachers to support and develop children's talents is one of the most important among them. In this regard, it is necessary to prepare teachers for the activities aimed at identifying, training and developing gifted children. To solve this problem in the city of Abakan, a programme of the training seminar "Organization and Holding of the All-Russian Olympiad in the Municipal Education System" has been developed (Table 3).
The training seminar for Abakan teachers has been held annually since 2016. More than a thousand teachers visit this seminar annually. The seminar gives an opportunity to increase the level of organization and holding of the school and municipal stages of the All-Russian School Olympiad in the town. Teacher training is organized in conventionally allocated groups. According to the practical experience, the existing system of organizing work with gifted children and providing pedagogical support to teachers in the preparation of the All-Russian Olympiad participants contributes to the effectiveness of the Abakan city team participation in the Olympiad movement.

\section{Conclusion}

It can be concluded that the organization and holding of the All-Russian School Olympiad in the municipal education system requires specifically created pedagogical conditions. The organization of teacher training for organizing and holding the All-Russian School Olympiad in the municipal education system will allow teachers to get ready to

Table 3. The programme of the training seminar "Organization and Holding of the all-Russian Olympiad in the Municipal Education System"

\begin{tabular}{|l|c|c|}
\hline \multicolumn{1}{|c|}{ Thematic block } & $\begin{array}{c}\text { Group } \\
\text { of organization- } \\
\text { al support }\end{array}$ & $\begin{array}{c}\text { Group } \\
\text { of psychological and } \\
\text { pedagogical support }\end{array}$ \\
\hline Legal support of the Olympiad & 1.5 hours & 1 hour \\
\hline $\begin{array}{l}\text { Features of the organization and holding of the school and } \\
\text { municipal stages in the city }\end{array}$ & 1 hour & 0.5 hours \\
\hline Psychological support of participants & 0.5 hours & 0.5 hours \\
\hline Formation of the database of the Olympiad participants & 0.5 hours & 0.5 hours \\
\hline $\begin{array}{l}\text { Filling out the Olympiad documentation (reports, protocols, } \\
\text { registration sheets, etc.) }\end{array}$ & 0.5 hours & 1 hour \\
\hline Material and technical equipment of the Olympiad & 0.5 hours & 0.5 hours \\
\hline Coding and decoding works of the Olympiad participants & 0.5 hours & 1 hour \\
\hline Preparing tasks for the school stage of the Olympiad & & 2.5 hours \\
\hline $\begin{array}{l}\text { Diagnostics of students' development to develop the Olympi- } \\
\text { ad preparation programme }\end{array}$ & & 0.5 hours \\
\hline $\begin{array}{l}\text { Development of individual plans for preparation for the sub- } \\
\text { ject Olympiads }\end{array}$ & & \\
\hline Approaches to solving tasks on the Olympiad subject & & \\
\hline $\begin{array}{l}\text { Specific features of assessing the Olympiad tasks solutions } \\
\text { on the Olympiad subject }\end{array}$ & & \\
\hline
\end{tabular}


work with gifted children on the job, which allows to solve the problem of maximizing the potential of each child in any municipal educational institution. Preparation for the organization and holding of the All-Russian
School Olympiad in the municipal education system requires an even more detailed consideration, since formation of a harmoniously developed generation of a given municipality depends on it.

\section{References}

Adol'f, V.A., Golubnichaya, E.V. (2013). O rezul'tatakh anketirovaniia uchastnikov munitsipal'nogo etapa vserossiiskoi olimpiady shkol'nikov [On the Results of the Survey of Participants of the Municipal Stage of the All-Russian School Olympiad]. In Vospitanie shkol'nikov [Education of School Students], 8, 23-34.

Chegodaev, A.V. (2013). Uchastie vologzhan vo Vserossiiskoi olimpiade shkol'nikov: rezul'tativnost' i puti razvitiia [Participation of Vologda Residents in the All-Russian School Olympiad: Efficiency and Ways of Development]. In Ekonomicheskie i sotsial'nye peremeny: fakty, tendentsii, prognoz [Economic and Social Changes: Facts, Trends, Forecast], 2, 185-193.

Esipova, A.A., Hokhlov, A.A. (2017). Analiz opyta provedeniia vserossiiskikh predmetnykh olimpiad shkol'nikov [Analysis of the Experience of Holding the All-Russian Subject School Olympiads]. In Molodoi uchenyi [Young Scientist], 11(2), 58-60.

Ivanov, S.A. (2016). Izuchenie konstitutsionnogo prava rossiiskoi federatsii i zarubezhnykh gosudarstv $\mathrm{v}$ ramkakh raboty po podgotovke k olimpiade po pravu [The Study of the Constitutional Law of the Russian Federation and Foreign Countries in the Framework of the Preparation for the Olympiad in Law]. In Olimpiadnoe dvizhenie: problemy i perspektivy razvitiya [Olympiad Movement: Challenges and Development Prospects]. Moscow, College of Modern Technologies named after Hero of the Soviet Union M.F. Panov, 84-95.

Kobzeva, N.I., Kobzeva, M.A. (2016). Olimpiada shkol'nikov - pokazatel' effektivnosti uchebnogo processa [School Olympiad as an Indicator of the Educational Process Effectiveness]. In Molodoi uchenyi [Young Scientist], 23, 486-489.

Kolomoets, K.S. (2017). Organizatsiia i provedenie olimpiady v srednei obshcheobrazovatel'no' shkole [Organization and Holding the Olympiad in the Secondary General School], In Aspekty i tendentsii pedagogicheskoi nauki [Aspects and Trends of Pedagogical Science], Sankt-Petersburg, Svoe izdatel'stvo, 124126.

Laletin, N.V. (2010). Kliuchevye faktory razvitiia olimpiadnogo dvizheniia shkol'nikov v krasnoiarskom krae [Key Factors in the Development of School Olympiad Movement in Krasnoyarsk Region]. In Vestnik Krasnoiarskogo gosudarstvennogo pedagogicheskogo universiteta im. V.P. Astaf'eva [Bulletin of Krasnoyarsk State Pedagogical University named after V.P. Astafyev], 2, 34-40.

Prikaz Ministerstva obrazovaniia i nauki RF ot 18 noiabrya 2013 g. № 1252 "Ob utverzhdenii poryadka provedeniia vserossiiskoi olimpiady shkol'nikov' (s izmeneniyami i dopolneniyami) [Decree of the Ministry of Education and Science of the Russian Federation of November 18, 2013, No. 1252 "On Approval of the Procedure for Holding the All-Russian School Olympiad (as Amended and Supplemented)].

Rozhdestvenskaya, I.N. (2013). Razvitie sistemy podgotovki shkol'nikov k uchastiiu vo Vserossiiskoi olimpiade v usloviiah munitsipal'nogo obrazovaniia [Development of the System of School Students Training for the Participation in the All-Russian Olympiad in the Context of Municipal Education]. In Pedagogika i psikhologiia [Pedagogy and Psychology], 3, 122-132.

Sal'nikova, N.L. (2016). Iz istorii olimpiadnogo dvizheniia v Rossii [From the History of the Olympiad Movement in Russia], In Olimpiadnoe dvizhenie: problemy i perspektivy razvitiya [Olympiad Movement: Challenges and Development Prospects]. Moscow, College of Modern Technologies named after Hero of the Soviet Union M.F. Panov, 47-51.

Senicheva, N.N., Sokolova, D.V. (2015). Uchastie v konkursakh i olimpiadakh kak forma razvitiia odarennosti obuchaiushchikhsya [Participation in Competitions and Olympiads as a Form of Students' Talents Development]. In Voprosy territorial'nogo razvitiia [Territorial Development Issues], 9 (29), 5. 
Yanova, M.G. (2013). Osnovnye kontseptual'nye polozheniia stanovleniia i razvitiia organizatsionno-pedagogicheskoi kul'tury budushchego pedagoga $\mathrm{v}$ tranzitivnom obrazovatel'nom prostranstve: tekhnologicheskie elementy [Basic Conceptual Regulations of Forming and Developing of Organizational and Pedagogical Culture of a Future Teacher in Transitive Educational Space: Technological Elements]. In Alma Mater, 7, 67-72.

\title{
Особенности подготовки педагогических работников к организации и проведению Всероссийской олимпиады школьников в муниципальной системе образования
}

\author{
Е.В. Голубничая, М.Г.Янова \\ Красноярский государственный педагогический \\ университет им. В.П. Астафьева \\ Российская Федераичия, Красноярск
}

\begin{abstract}
Аннотация. В статье рассматриваются особенности подготовки педагогов к организации и проведению Всероссийской олимпиады в системе муниципального образования. Обосновывается необходимость и актуальность организации подготовки педагогических кадров для организации и проведения олимпиады в системе муниципального образования. Особое внимание уделено нормативным документам, регламентирующим порядок проведения олимпиады. Рассмотрен опыт подготовки учителя к организации и проведению Всероссийской олимпиады школьников в муниципальной системе образования. Представлена программа обучающего семинара «Организация и проведение Всероссийской олимпиады в системе муниципального образования».
\end{abstract}

Ключевые слова: Всероссийская олимпиада школьников, организация и проведение олимпиады, подготовка учителей.

Научная специальность: 13.00.01 - общая педагогика, история педагогики и образования. 